(REVIEW ARTICLE)

\title{
Health implications of kolanut production and consumption
}

\author{
Chinweike Abednego Ugwu *, Modinat Adewunmi Alli, Kehinde Ademola Adesanya, Mutiat Oluwaseyi \\ Agboola-Adedoja, Adejoke Adebusola Adelusi, Qudus Adebayo Ogunwolu and Ayodele Oladipo Akinpelu \\ Economics and Extension Department, Cocoa Research Institute of Nigeria, P.M.B. 5244, Ibadan, Oyo State, Nigeria \\ 1234567.
}

Publication history: Received on 13 December 2020; revised on 21 December 2020; accepted on 23 December 2020

Article DOI: https://doi.org/10.30574/wjarr.2020.8.3.0485

\begin{abstract}
This study examined the health implications of kolanut production and consumption. A desk research was done using past published literatures. The study outlined the effect of ill health on agricultural production. Numerous health benefits of kolanut consumption were identified despite several possible side effects when consumed in large quantity overtime. Benefits of kolanut consumption out-weigh the negative implications. Kolanut consumption should be encouraged as it is useful in treating some illnesses that otherwise will cost fortune when treated with conventional drugs. Also with the reported occurrence of Ochratoxin (A), safe and clean storage and shelf on-sale practices are encouraged. Government should also motivate more research on kolanut utilization in food and drug industries in order to stimulate production as this would also help boost the Gross Domestic Product (GDP).
\end{abstract}

Keywords: Kolanut; Production; Consumption; Health implication

\section{Introduction}

Kolanut belongs to the family Sterculaceae. It is produced mostly in Africa and is cultivated to a large quantity with outstanding growth performance in Nigeria. Ghana, Ivory Coast, Brazil and the West Indian Islands also cultivate kolanut [1]. According to [2], Nigeria accounts for about 50.2 percent of the total world production of kolanuts, Ivory Coast, 19.3 percent, Cameroon, 18.3 percent, Ghana, 9.0 percent, Sierra Leone, 3 percent, and Benin, 0.2 percent, respectively. Annual production from these countries alone is in excess of 250,000 tons, while with respect to their cultivation, processing, and storage, world production is about 300,000 tons [3].

Kolanut production is predominant to tropical rainforests of Africa [4]. There are about 40 kola species dominant in West Africa. However, the kola species of economic importance especially in Nigeria, West and Central Africa, the Caribbean Islands, Mauritius, Sri Lanka and Malaysia are Cola acuminata and Cola nitida [5]. Kolanut is a lowland tropical crop that grows well between latitude $6 \mathrm{No}$ and south of the equator. It grows best in regions with an annual rainfall ranging from 1250-1750mm and a wellmarked dry and wet season. The most suitable soil for kolanut cultivation is a well-drained fertile soil that is rich in humus [6].

According to [1], there is a common saying in Nigeria that kolanut is produced in the West by Yorubas, consumed in the North by Hausas and worshiped in the East by Ibos. The different local names for kolanut in the three major tribes in Nigeria are Yoruba (obi), Hausa (goro) and Ibo (oji).

Despite rising demand, the production remains low because many of the trees especially in Nigeria are unfruitful or have very low yield due to self-and-cross incompatibility among trees, partial and total sterility, inefficient natural

\footnotetext{
${ }^{*}$ Corresponding author Chinweike Abednego Ugwu

Economics and Extension Department, Cocoa Research Institute of Nigeria, P.M.B. 5244, Ibadan, Oyo State, Nigeria.
} 
pollination, old age, field and storage pests, and diseases [1]. It was reported that about 10 percent of the kolanut produced in Nigeria is exported while 90 percent is consumed within the country [5].

Kolanut is used as a masticatory stimulant by Africans and has numerous uses in social, religious, ritual, and ceremonial functions by the natives in the forest region of Africa [7]. It is used during ceremonies related to marriage, child naming, and installation of Chiefs, funeral, and sacrifices made to the various gods of African mythology [8]. Meanwhile the principal chemical constituents of kolanut are caffeine, theobromine and theophylline which are xanthine derivatives [9]. According to [10], caffeine produces stimulatory effects on the cardiovascular and neuroendocrine systems when consumed in large quantity. In addition, research by [11] also confirmed that caffeine ingestion heightens the stress response by stimulating the release of stress-associated hormones such as cortisol, epinephrine and norepinephrine. Continued presence of these hormones in the body not only has a damaging impact on some physiological systems, but can also accelerate the ageing process. The immune system is suppressed, digestion and elimination of waste are impaired and the body repair mechanisms are inhibited thereby accelerating aging process [12]. In spite of this, kolanut is greatly used by many professionals as a principal stimulant to keep awake and resist fatigue. Furthermore, studies have shown that intake of kolanut and caffeine-containing beverages stimulate inflammatory response [9]. Nevertheless, the occurrence of ochratoxin (A) - a toxic metabolite produced in kolanuts reported to be carcinogenic, immunotoxic, genetoxic, immunosuppressive, nephrotoxic reflects the need for a review on the health implications of production, storage and consumption of kolanuts [13]

A desk research was articulated using past published literatures to achieve the objectives of the study which included an outline of the health benefits associated with kolanut consumption, and enumerating the negative health implications of kolanut production and consumption.

\section{Health and kolanut production}

The importance of health as a form of human capital cannot be underestimated. Good health and productive agriculture are important in the economy of any nation especially in the fight against poverty [14]. Similarly health enhances work effectiveness and the productivity of an individual through increase in physical and mental capacities. Health affects agricultural system by affecting the health of the producers. Poor health will result in loss of work days, decrease innovativeness and ability to explore diverse farming practices [15]. Thus, ill health leads to decrease in kolanut output due to ineffective supervision of farms. According to [16], a farmer loses on the average 22 working days when incapacitated by one sickness or the other per time. Similarly, [17] reported that poor health has a huge effect on production though it is difficult to quantify. They also opined that food consumption could have both positive and negative health implications. Summarily, [18] captured the interaction between health and farm-labour productivity as shown in figure 1 below

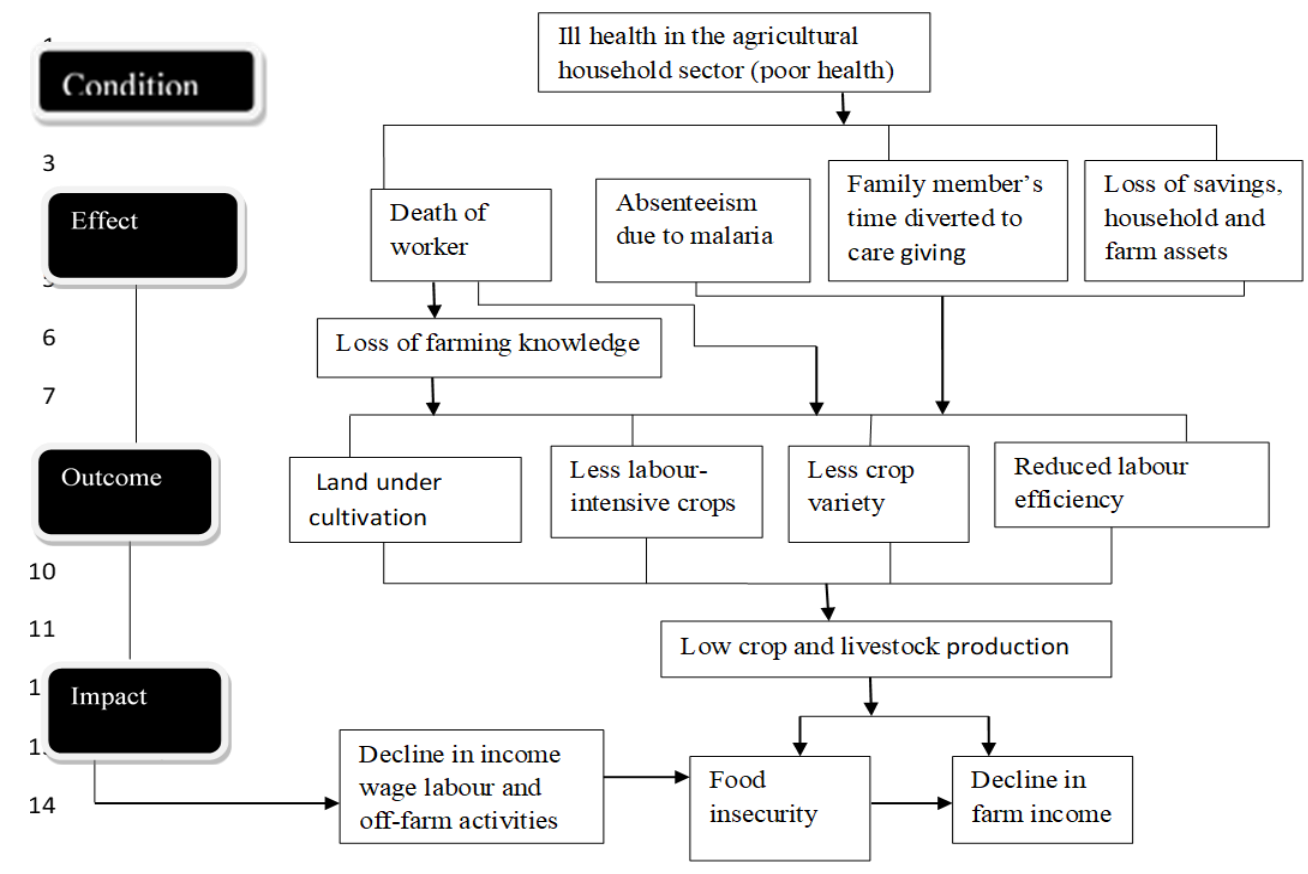

Figure 1 Conceptual framework for the impact of illness/diseases on agriculture. Source: Kwadwo et al, 2011 


\section{Potential health benefits and implications of kolanut consumption}

The many health benefits of kolanut go back thousands of years. Kolanut has been listed by the United States Food and Drug Administration [19] as generally safe for human consumption. People have claimed that kolanut sweetens stale water, treats fatigue and eases hunger. While kolanut may have health benefits, research shows that they have yet to be specifically researched and proven. The high caffeine content, which increases energy and reduces hunger is the connect of most of its alluded benefits.

It has also been reported that kolanut treats infections, skin diseases, ulcers, toothaches and or sore gums, morning sickness, intestinal diseases, headaches, depression, low sex drive, coughs and asthma, dysentery, constipation, and eye problems respectively [19]. It also aid digestion, remedy hangovers, aids difficult labour, regulates menstrual cycles, improves gastrointestinal health, boosts mental health, treats respiratory issues [20]. These benefits according to [20] may be because the anatomy of kolanut shows that it contains several compounds including caffeine, theobromine, tannins, catechins.

Kolanut extract is classified as natural food flavouring. The FDA has also approved kola extract as an active ingredient in certain pharmaceuticals. However, the American Herbal Products Association includes kolanut on a list of caffeinecontaining substances that should not be used by pregnant or breast feeding women or those under the age of 18 [19].

According to [21] several benefits of kolanut and its products include the following:

- Boost to metabolism: kolanut products contain caffeine, which may give a person's metabolism a boost.

- Aid to digestion: kolanut powder and extract may help digestion. They are thought to promote the production of gastric acid, which increases digestive enzyme effectiveness in the stomach.

- Increase in blood circulation: the caffeine and theobromine in kolanut may speed up the heart rate, which increases circulation of the blood.

- Boost to energy levels: kolanut naturally stimulates the central nervous system (CSN) which may increase alertness and boost energy levels.

- Antibacterial benefits: studies indicate that, the use of kolanut extract might stop the growth of harmful bacteria.

Research indicates kolanut do have antimicrobial properties that might fight dental pathogens and possibly other infections [20].

In the same vein, although extensive studies have not been conducted, early research as reported by [21] indicates that:

- Certain compounds found in kolanut may decrease the risk of prostate cancer. This research though been debated, reveals that phytoestrogens in kolanuts may kill cancer cells and stop tumors from growing.

- Migraines: kolanut may be helpful for people who have migraine headaches. Migraines often affect the blood vessels in the head and caffeine has been used for headache pain. Again, the theobromine and caffeine contained in the kolanut may dilate or widen blood vessels in the brain which might decrease migraine pain.

- Asthma: Although not recommended as a treatment for respiratory conditions, kolanuts might be used for people with certain breathing problems such as asthma. It is thought that the caffeine in kolanuts may act as a bronchodilator, which means it opens the airways to make breathing easier.

[20] Enumerated some side effects of kolanut consumption to include jitters, dehydration, increased blood pressure, impaired calcium absorption. He also opined that these side effects vary from individual to individual depending on the body reactions.

Similarly, [21] listed some negative health effects to include, increasing the release of stomach acid, which can lead to heartburn and stomach upset; interfering with the body's ability to absorb calcium and increasing blood pressure. 


\section{Conclusion and Recommendation}

The paper examined health implications on production, and consumption of kolanut. It was revealed that the main active compound in kolanuts is caffeine. Given the numerous negative health implications kolanut pose when consumed in large quantity over time, it should be taken in moderate quantity. Also with the reported occurrence of ochratoxin (A), safe and clean storage and shelf on-sale practices are encouraged. Extension agents should create more awareness on the numerous health benefits of kolanut consumption to encourage its use in treating some of the illnesses as this will reduce the amount spent on conventional drugs.

Since positive benefit of kolanut consumption out-weighs the negative implications, controlled consumption should be encouraged. Government should motivate more research on kolanut utilization in food and drugs industries in order to stimulate production as this would help boost the Gross Dosmestic Product (GDP).

\section{Compliance with ethical standards}

\section{Acknowledgments}

I wish to express my gratitude to my mentor, Dr A O Akinpelu, who guided me throughout this study. I would also like to thank my coauthors for their outstanding contributions in this study.

\section{Disclosure of conflict of interest}

The authors declare that they have no conflict of interest.

\section{References}

[1] Asogwa EU, Otuonye AH, Mokwunye FC, Oluyole KA, Ndubuaku TCN, Uwagboe EO. Kolanut production, processing and marketing in the South-eastern states of Nigeria. African Journal of Plant Science. 2012; 5(10): 547-551.

[2] Food and Agriculture Organization statistics; Countries by commodity. FAO, Rome, Italy. Food and Drug Administration (2019). Accessed 21 October 2020.

[3] American Horticultural Society. The American Horticultural Society Encyclopedia of Flowers. D.K. Publishing: New York. 2002.

[4] Money Management Series Plus. How to start kola nut export business. Lagos: Kings Communications Limited; C) 2018(cited 2020 Oct 29). Available from https://mmsplusng.com/blog/how-to-start-kola-nut-exportbusiness

[5] Ndagi I, Babalola FD, Mokwunye IU, Anagbogu CF, Aderolu IA, Ugioro O, Asogwa EU, Idrisu M, and Mokwunye FC. Potentials and Challenges of Kolanut Production in Niger State, Nigeria. International Scholarly Research Network Agronomy. 2012; (10): 1-9.

[6] Uguru MI. Crop production; Tools, Techniques and practices. 2011; 130.

[7] Asogwa EU, Anikwe JC, Mokwunye FC. Kola production and utilization for economic development. African Scientist. 2006; 7(4): 217-222.

[8] Opeke LK. Tropical Commodity Tree Crops. Spectrum Books Limited, Ibadan, Nigeria. 2005.

[9] Bassini-Cameron A, Sweet E, Bottino A, Bittar C, Viega C, Cameron L. Effects of caffeine supplementation on hematological and biochemical variables in elite soccer players under physical stress conditions.British Journal of Sports Medicine. 2007; 41: 523-30.

[10] James JE. Critical Review of dietary caffeine and blood pressure: a relationship that should be more serious. Psychosomatic Medicine. 2004; 66(1): 63-71.

[11] Rafetto M, Grumet T, French G. Effects of caffeine and coffee on cardiovascular diseases including high blood pressure, arrhythmias and high cholesterol.Teeccino café incorporated. 2004.

[12] Leonard B. Stress, depression and the activation of immune system. World Journal of Biological psychiatry. 2000; 1(1): 17-25. 
[13] Dongo LN, Manjula K, Orisajo SB. Occurrence of Ochratoxin A in Kolanuts. Annual Report of Cocoa Research Institute of Nigeria. 2007; 28.

[14] Akinpelu AO, Amamgbo LEF, Olojede AO, Oyekale AS. Health implications of cassava production and consumption.Journal of Agriculture and Social Research. 2011; 11(1): 118-125.

[15] Ajani OIY, Ugwu, PC. Impact of Adverse health on Agricultural Productivity of Farmers in Kainji Basin NorthCentral Nigeria Using a Stochastic Production Frontier Approach. Trends in Agricultural Economics; 2008; 1(1): 1-7.

[16] Ugwu PC. Effect of farmers' health on the agricultural productivity of the principal farm operator in Borgu Local Government Area of Niger State. Unpublished M.Sc Project, University of Ibadan, Ibadan, Nigeria. 2006.

[17] Nuggent R. Drescher A. Impacts of inputs to Agricultural systems: Understanding the links between Agriculture and Health for food, Agriculture and the Environment. In: Agriculture, Environment, and Health: Toward Sustainable Solutions. 2006 Focus 13. 2016; Brief 14 of 16.

[18] Kwadwo AO, Chiang C, Thangata P, Kwaw SA. Interaction between health and farm-labour productivity. International Food Policy Research Institute. Washington, DC. 2011.

[19] Osborn CO. What is Kolanut? San Francisco: Healthline Media; C2018 (cited 2020 Oct 29). Available from http://www.healthline.com/health/kola-nut

[20] Beyer AL. Curious about the kolanut? Here are the Deets. 2020. San Francisco: Healthline Media; (C2020 (cited 2020 Oct 29). Available from http://greatist.com/health/kola-nut

[21] Pietro DM. Health benefits of kolanut. United Kingdom: healthline Media; (C) 2017(cited 2020 Oct 29). Available from https://www.medicalnewstoday.com/articles/319626\#how-is-the-kola-nut-used 